S-1-1 心筋梗塞による心原性ショックに対する 緊急 $\mathrm{A} ・ \mathrm{C}$ バイパス手術の検討

榊原記念病院 心臟血管外科

維田隆夫, 万納寺栄一, 加瀬川 均, 川瀬光彦

急性心筋梗塞(AMI)に伴う心原性ショックに対す る手術成績はいまだ満足すべきものではないが, われ われの心原性ショックに対する緊急 $\mathrm{A} ・ \mathrm{C}$ バイパス手 術の経験から, 手術成績向上のための要因を検討した。 【対象】過去 17 年間に, 44 例の心原性ショック症例に 対して手術を行った。これらは当施設における $\mathrm{A} ・ \mathrm{C}$ バイパス手術症例の $3.9 \%$ にあたる。症例は男性 38 例, 女性 6 例, 年齢は 36 81 歳(平均 $63 \pm 9.7$ 歳)で, 心 原性ショックの直接原因は, AMI 26 例(Sustained VT 1 例を含む), PTCA, PTCRの合併症 14 例, DCA の合併症 1 例, CAG の合併症 3 例であった。

【方法および結果】手術はすべて緊急手術であり，8例 はカテーテル室, 2 例はCCUで手術を行った。IABP は全例に使用し， 7 例に Coronary Reperfusion Catheter $(\mathrm{CRC})$ が挿入された。 $\mathrm{A} ・ \mathrm{C}$ バイパス手術は, 1 本バイパス 11 例, 2 本バイパス 22 例, 2 本バイパス + 上行大動脈人工血管置換術 1 例, 2 本バイパス $+\mathrm{ERP}$ $+\mathrm{ECA} 1$ 例, 3 本バイパス 6 例, 4 本バイパス 3 例であ った。心筋保護液は, Cold Crystalloide (CC) 15 例, Cold Blood(CB) 13例, Warm Blood (WB)3 例, CB + Terminal WB(TWB) 12 例, 心拍動下手術 1 例であ った。人工心肺離脱は 40 例が可能であったが, 術後 1 年以上の長期生存は 28 例であった。生存症例は, 術前 CPRが6例に施行され, CRC を6 例に使用した。冠動 脈の血行再建度は, 16 例に完全冠血行再建がなされ, Incomplete Satisfactory(IS)は 9 例, Incomplete Unsatisfactory(IU)は3 例のみであった。心筋保護 は, CC 6例, CB 9例, WB 2例, CB + TWB 10例, 心拍 動下手術 1 例であった。一方, 死亡例 16 例の死亡原因 は, 人工心肺離脱不能 4 例, 術直後のポンプ不全 5 例, 脳障害 3 例, 多臟器不全 3 例, 重症心不全 1 例であった。 術前 CPRは 9 例に施行され, CRCは1例のみに使用さ れた。完全冠血行再建がなされたのは 4 例, IS は 4 例, $\mathrm{IU}$ は 8 例で, 特に人工心肺離脱不能症例 4 例はいずれ もIUであった。心筋保護は, CC 9 例, CB 4 例, WB 1 例, $\mathrm{CB}+\mathrm{TWB} 2$ 例であった。

【考案】心原性ショックに対する緊急 $\mathrm{A} ・ \mathrm{C}$ バイパス手 術では, 速やかな IABPや $\mathrm{CRC}$ の使用, WB, CB + TWB は有用である。人工心肺の離脱に難渋した症例 には不完全冠血行再建症例が多く,かつ生存率が低か ったことを考慮すると，紫急手術といえども生存率の みならず長期予後を良好とするためには, 出来る限り 完全冠血行再建を行うことが必要と考えられる。
S-1-2 術前 I A B P 補助を要した急性心筋梗塞症 例に対する冠動脈バイパス術

日本赤十一字社和歌山医療センター心臓血管外科

松本雅彦. 小西 裕. 湯浅貞稔, 三和千里

【目的】術前 I A B P 補助を要した急性心筋梗塞( AMI ) 症例に対する冠動脈バイパス術 (CABG) 成績を術前因子, 手術時期から検討した。

【対象】1988年 1 月〜 1995年 7 月の期間の当科でのC A B G 478例中, 手術まで術前 I A B P 補助を継秸し た症例は80例で, AM I 後の単独C A B G（左室瘤。 心破裂，弁合併手術例を除く）40例を対象とした。こ の中 6 例はcoronary perfusion catheter を併用した . 入院死亡 6 例 (LOS 4 例. MNMS 2 例). 遠隔 死亡 1 例（29月後. 突然死）. 術後の I A B P 補助期 間（入院死亡例を除く）は 1 日以内17例. 2 日 8 例.

3 日 4 例. $5 \sim 13$ 日 5 例. 入院死亡に及ぼす術前因子 を検討し， $\mathrm{p}<0.05$ を有意とした.

【結果】入院死亡例数/症例数で記載.

\begin{tabular}{lccc} 
& YES & N O & p值 \\
\hline Female & $0 / 12$ & $6 / 28$ & $\mathrm{~ns}$ \\
Age 70歳以上 & $4 / 11$ & $2 / 29$ & $<0.05$ \\
LVEF 40\%以下 $*$ & $3 / 11$ & $1 / 7$ & $\mathrm{~ns}$ \\
Forrester III . IV & $5 / 13$ & $1 / 27$ & $<0.01$ \\
右室梗塞 & $3 / 5$ & $3 / 35$ & $<0.02$ \\
LMID. 3VD & $6 / 29$ & $0 / 11$ & $\mathrm{~ns}$ \\
\hline
\end{tabular}

*22例で術前左室造影未施行

AMI から再灌流までの時間（再灌流時間）を見ると

$$
\begin{aligned}
& \text { 12時間以内 } 2 / 19 \quad(0 / 16) \\
& 12 \text { 時間 }<.3 \text { 日以内 } 3 / 12 \quad(3 / 12) \\
& 3 \text { 日 }<\text {. 21日以内 } 1 / 9 \quad(0 / 7) \\
& \text { ( ) =術前右室梗塞合併例老除外 }
\end{aligned}
$$

入院死亡率と再灌流時間に有意差は見られなかった。

【考察・結語】高齡者. Forrester III. IV型は危険因 子と言えるが, とりわけ術前右室梗塞合併例は予後不 良であった. 術前右室梗塞を合併した5例について見 ると. 再灌流時間 12 時間以内の 3 例中 2 例加死亡. 救 命した 1 例も心不全のため術後 8 日間 I A B P 補助を 要した.これに対し再灌流時間15日の 1 例をMNMS で失ったが、再灌流時間13日の1例は術翌日 I A B P から離脱でき経過順調だった。

右室梗塞は内科治療が有効で $1 \sim 2$ 週間で回復が得 られる.一般に梗塞の進展を防ぐためにはAM I 発症 早期に再灌流が計られるが、術前右室梗塞合併例では I A B P 補助を含む内科治療で急性期をしのいだ後の 準緊急手術を考虑する必要があろう. 
S-1-3 術前LABPを必要とした虚血性心疾患の緊 急手術86例の検討

熊本中央病院 心臓血管外科

坂田隆造 梅林 雄介 植山 浩二 中山 義博 浦 正史 新垣 勝也

（目的）IABPは心原性shockの治療手段として用い られる場合 (A群) と,楽物抵抗性の不安定狭心症に用 いられる場合 (B群) があるがこの 2 群の手術予後は 大きく異なる。これらを比較し、それぞれの救命のポ イントについて検討する。なおAMIでLABPにより短時 間にshock状態より回復した例はB群に含め、機械的合 併症は除外した。

（対象と方法）A群は23例で年齢50 83歳(平均67.8) 内訳はAMI13例、切迫梗塞 7 例、PTCA trouble 3 例で あり、LMTは14例(61\%) 3VD 2 例であった。心肺蘇 生を要したものは10 例あり、そのうち 3 例は心荿マ ッサージ下に手術を開始した。術前のIABP support時 間は16例(70\%)が 5 時間以内で、5 24時間が 5 例、 24 時間以上は 2 例であった。IABP下に術前palliative PTCA又はthrombolysisを施行したのは10例でperfusion catheterを 5 例に使用した。B群は63例で年齢50 85歳(平 均68.6)、内訳はAMI12例、不安定狭心症51例であっ た。LMTは34例(54\%)で3VD(without LMT)は24例、 prior MIは38例(60\%)であった。術前IABP時間は1 5時 間19例、5 24時間10例、1 5日16例、5 10日10例、 10 20日8例であった。graftはA群でほぼ全例SVGであ ったのに対し、B群ではSVGのみ29例、左IMA+SVG29 例、両IMA+SVG 3 例、左IMA+GEA 2 例であった。こ の 2 群について大動脈遮断時間(AoT)体外循環時間 (ECT)、挿管時間(Intu.T)、Inotoropic support時間(InoT)、 術後LABP時間(BPT)の各項目を比較検討した。

(結果) A群の死亡は 2 例(8.7\%)でいずれも心臓、 ッサージ下に搬入したものであり術後早期のLOSであ った。B群では 7 例(11.1\%)の死亡があったか、この内 5 例は55 180日後であり、IABPからは離脱できてい たが主に感染によるMOFが死因であった。(AoT)は両 群とも80 90分で差はなかったが、(ECT)はA群186.3土 110.3分、B群127.1土35.6分でA群が有意に長かった。 術後因子では(Intu.T),(InoT),(BPT)いずれでもA群の方 が有意に長時間を要した。

（結論）A群では手術開始までの血行動態の維持が 重要で、時間の短縮と共にcatheter interventionによる適 切なassistが有効であった。B群では感染症が重大な結 果をもたらしており、術前LABP で安定化が得られた としても早期に手術を行い速やかにIABPを抜去する ことが必要であると思われた。
S-1-4 術前から復噮補助を要した歎治性心筋 虚血に対する緊急CABG症例の検討

\section{岐皁県立岐皁病院 胸部外科}

滝谷博志、澤村俊比古、村瀨恭一、河合寿一、 水谷憲威、大野貴久

【目的】近年の冠動挢インターベンション の発達にもかかわらず、内科的治療では限界のあ る急性心筋虚血（ARMI）や、インターベンション による合併症のため、㷂急CABGを要する症例も多 く、その治療成績は必ずしも良好ではない。そこ でこれら疾患群の成績向上を計るため自験例の背 景因子、成績を検討した。【対象と結果】当院に おける術前からIABPなどの循環溨助を要した難治 性心筋虚血（ARMI）に対する婜急CABG症例は63例 で、疾患の内訳はUAP群10例、EMI (AMI) 群15例、I MI群25例、PTCA群（PTCA、冠動䏡造影の合併症な ど）13例で、LMTの高度狭窄例が30例48\%、0MIが 36例 $57 \%$ を占めていた。UAP群では重症 3 枝病変 ないしLMT病変が10例中 9 例であり、EMI+IMI群40 例は院内発症ないし救命センターに搬入されたAR MI例で同期間のAMI症例840例の4.8\%であった。 PTCA群中11例はPTCA、DCAによる合併症で、2895回 のPTCA中 $0.38 \%$ の発生顉度で、残る 2 例は 14950 回の冠動䏡造影で発症したLMT閉塞例であった。 循環補助としてIABPを63例全例に使用し、PCPSは 1 例、PTCAによる閉塞 3例にパーフュージョンカ テーテルを用いた。ショック例は、20例32\%、心 肺蘇生を要した重症例は 9 例14\%で、PTCA群でと くに高率であった。体外循噮襍脱不能例 4 例にPC PS、左心バイパスを使用し、1 例は左心バイパス より嚄脱したが、結果的に全例を失った。手術成 績は手術死亡10例16\%、病院死亡4 例6.3\%、計1 4例22\%であり、死因は心峺死 5 例7.9\%、非心巏 死 9 例 $14 \%$ と術後合併症による死亡例が多かった 。70才以上高踰者は 10 例中 5 例 $50 \%$ の死亡率で著 しく不良であった。11年間を前期 5 年、後期 6 年 に分けると前期 $32 \%$ から後期 $12.5 \%$ と死亡率は著 しく改善したが高豨者では改善傾向はみられなか った。【考察】当院で报うAMIの増加にもかかわ らず、directPTCAの導入により㗨急CABGの頻度は 年々娍少㑯向にある。またその手術成績も、最近 6 年間では $12.5 \%$ と待期手術の $1.6 \%$ には劣るも のの改善していた。手技の向上とともに、㗨急手 術に対する院内の体制が確立されつつあるものと 考える。機械的循環補助を駆使し術前の血行動態 と冠血流の雄持を計り、術後合併症の予防に努め ることが成績向上をもたらすと考える。 
S-1-5 術前より I ABPを要したacute coronary syndormeに対する緊急冠動脈バイパス術

\section{東京女子医科大学日本心荿血圧研究所循環器外科}

西田 博, 富岡秀行, 椎川 彰, 冨澤康子, 遠藤真弘, 小柳 巨

【目的】術前より I ABP 補助を要した症例に対する 緊急CABGの検討【対象】1995 年 7 月までの単独 CABG 1939 例中、術前より IABP dependentであっ た 138例 (7.1\%) を対象とした。予防的 I ABP とPTCA 合併症に対する緊急CABG は除外した。年齢は40〜84. 平均 63.1 歳 (70歳 $\geqq$ : 38例、 $27.5 \%$ )、男 108 、女30例 で、高齢者、女性が多数を占めた。観察期間は 1 力月 〜 17.5年、平均 5.5 年であった。【結果】(術前因子 …不安定狭心症60例、急性心筋梗塞53例、梗塞後不安 定狭心症25例で、71例が心筋梗塞の既往を有し27例が 前十後下壁の広範囲梗塞であった NYHAIV度18例。 ショック28例 (内LMSS:Left Main Shock Syndrome = LMT閉塞による広範前側壁梗塞に伴うショック 9 例)、 再 CABG 12例、慢性腎不全29例 (透析 7 例 )、心房細 動11例、Lown 分類 II 度以上の心室性不整脈15例を認 めた。病変枝数は 1 枝 $8 、 2$ 枝 $18 、 3$ 枝 $65 、$ LMT 病 変47例で 3 枝と LMT が81\%、主要 2 枝以上完全閉塞 27 例之PTCA 不適例が多数を占めた。LVEF を調べ得た 111 例中40例が40\%以下の低左心機能で II 度以上の僧 帽弁逆流を 7 例に認めた。(2)手術…血行再建数は平均 2.23、グラフト別吻合数は静脈 180、LITA：91、RITA

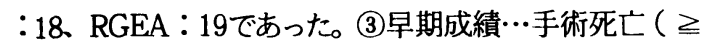
30日 ) 6 例 ( $4.3 \%$ : 心臟死 5 、非心臓死 1 )、病院死 亡（>30日） 9 例（6.5\%：心臓死 3 、非心臓死 6 ) で あった。ショック例：手術死亡 3 例 $(10.7 \%)$ 、病院死 亡 5 例 (17.9\%) (LMSS：手術死亡 2 例、病院死亡 2 例。CPR $\rightarrow$ 手術：2 例之も死亡。LMSS 以外：手術死 亡 1 例、病院死亡 3 例 )。非ショック例: 手術死亡 3 例 (2.7\%)、病院死亡 4 例 (3.6\%) であった。開存率 は動脈 91.4\% 静脈 95.5\%であった。(4) IABP 使用時 間之早期成績...手術死亡例以外は全例 IABP 離脱可能 であった。離脱例中、病院死亡例と生存退院例のI ABP 駆動時間の比較では術前 $(48 \pm 20$ v s 49 上 6 , N.S.)。術後 ( $86 \pm 20 \mathrm{vs} 43 \pm 4, \mathrm{p}=0.006)$ 之術後長期補助例で不良 であったが使用グラフトと生死の関係は認められなかっ た。術後100 時間以上 IABP 駆動例の病院死亡率は50\% （5/10）であったが、死因は腎不全 2、僧帽弁閉鎖不全 1、遷延する高度心不全 2 であった。(5)遠隔成績‥死亡 17例 (12.3\%、心臓死 7、突然死 2 、非心臓死 8 ) 、心 筋梗塞 4、再CABG 6、PTCA 13例で、5 年実測生存率 は 77.7\%( 全死亡) 、88.2\% (心蔵死のみ) 、心事故回 避率は73.2\%であった【結論】心筋壊死量の多い広範 囲梗塞例ほど予後不良であった。このような重症例では IABP 離脱後す厳密な心不全管理が重要である。
S-1-6 熙急CABGの成績と問題点

一術前血行動態からみた術式の選択一

大阪警察病院心䑏センター外科

榊原哲夫、松若良介、新谷英夫、矢倉明彦、吉川正人

<目的>腎急CABGの手術成績と遠隔成績を術前の血 行動態別に比較し、術前の血行動態の良否によって手 術術式を変更する必要があるかどうか検討した。

<対象及び方法>対象は叕急CABGのうち術前IABPPPC PSなどの循㻴補助装置を必要とした 72 例である。手 術時平均年龄は 66 歳、男性 56 例、女性 16 例で あった。急性心筋梗塞 45 例、切迫心筋梗塞 27 例で、 血管病変は左冠動脈主幹部、 3 枝病変、 2 枝病変、 1 枝病変それぞれ $30 、 36 、 5 、 1$ 例であった。これ らの症例を術前の血行動態より 3 群に分類した。IABP の挿入により狭心痛や心原性ショック controlできた 4 8例を 1 群、IABP後も心原性ショックが持続した17例 を 2 群、心原性ショックが極めて重篤でPCPSを装着し て手術場に搬送した 6 例を 3 群とした。全群ともグラ フトは大伏在静脈を用い原則として動脈グラフトは使 用しなかった。又術前の冠動脈造影所見などからキー グラフトを判定し、必ずしも完全冠血行再建を目指さ ずキーグラフトを中心に $2-3$ 本のグラフトを確実に 作成した。グラフト本数は $1 、 2 、 3 、 4$ 本それぞれ $8 、 32 、 31 、 1$ 例であった。手術遠隔期の追跡は 外来での面接又は紹介医一の電話によって行い追跡期 間は6ー162 カ月であった。

<成績 > 1） 72 例中 11 例を失い手術死亡率は 15 \%であった。2）1群では 48 例中 3 例（6\%）を失 い、そのうち 2 例 ( $4 \%$ ）が心原性死亡であった。2 群では 17 例中 4 例 $(24 \%)$ を失い 3 例 $(18 \%)$ が心原死亡であった。3 群では 6 例中 4 例 (6 6\%) を失い 2 例 ( $33 \%$ ) が心原死亡であった。平成 4 年 以降の 28 例では 2 例 $(7 \%$ ）を失ったが、共に 3 群 に属する症例であった。3）9年生存率は手術死亡を 含めると $72 \%$ であるが、心原性の遠隔死亡は認めな かった。4） 9 年の時点でのevent free rateは 68 \%であったが、eventの原因は全てキーグラフトのグ ラフト不全であった。5）遠隔成績は各群間に差を認 めなかった。

＜結語＞1）術前IABPでも心原性ショックをcontrol できない症例、特にPCPSを必要とする症例の手術成績 が不良であった。2）遠隔期のeventは比較的高率に 発生し原因はキーグラフトのグラフト不全であった。 3）術前IABPにより心原性ショックがcontrolできな い症例では完全血行再建を目指さず静脈グラフトによ るキーグラフト手術が、IABPにより心原性ショックが controlできる症例ではキーグラフトに動脈グラフト の使用が妥当であると思われた。 
S-2-1 手術成績よりみた問題点と成績向上のため の工夫

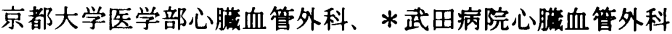
松田捷彦、*山里有男、*佐藤達朗、伴 敏彦

急性 $\mathrm{A}$ 型大動脈解離に対しては早期手術の有効性が 提唱されているが,その手術成績は必ずしも満足のゆく ものではない.今回我々は超急性期(発症 5 日以内) のA 型大動脈解離に対してその手術成績よりみた問題点と 成績向上のための工夫を検討した.【対象】1985年3月 より1995年8月までに、超急性期にA型解離と診断され た86例(内手術施行54例,48hr以内の手術は32例(59\%),32 例は手術までに死亡(13例,41\%),非適応(11例,34\%),拒否 (8例,25\%)により非施行)を対象とした.男性48例,女性38 例で,年齢は30歳より82歳,平均59.2歳であった.全症例に 対し術前あるいは術中に経食道エコー(TEE)を施行 し,entryの位置を確認し,血流開存型はすべて手術適応， 血流閉塞型は上行大動脈径が50 $\mathrm{mm}$ 以上を手術適応とし た.1991年以降はGRFglueを使用た.【結果】86例中65例 が血流開存型( I 群),21例が血流閉塞型( II 群)であった. I 群65例中,合併症を有したものは38例(58.5\%)であり, 心タンポナーデ21例，下肢虚血7例,LMT 圧迫3例,脳虚血3 例,左胸腔内破裂 2 例,略血,縦隔内破裂がそれぞれ1例で あった. II 群21例中合併症を有したものは9例 (42.9\%)で, 心タンポナーデ4例,左胸腔内破裂4例,脳虚血 1 例であっ た. I 群で合併症を有する38例中手術を施行したものは 25例 $(65.8 \%)$ で,上行置換17例, 上行〜弓部置換3例, 上行 entry patch 閉鎖,上〜下行置換,上行置換 $+\mathrm{CABG}$,上行 弓部置換+CABG,Bentall,それぞれ1例であった.手術死 亡13例(52\%)であった.非手術13例はすべて死亡(100\%) した.合併症を有さない27例中手術を施行したものは23 例( $85.2 \%)$ で, 上行置換9例, 上行〜弓部置換6例, 上行ring 装着, 上行置換 +第 1 枝再建, 弓部〜下行置換がそれぞれ 2例,上行entry patch閉鎖,上行置換+CABGがそれぞれ1 例であた.手術死亡3例(13.0\%)であった非手術4例中死 亡1例 $25 \%)$ であった. II 群で合併症を有する9例中5例に 手術を施行し,上行〜弓部置換 2 例,上行 entry patch 閉鎖, 上行置換, 上行 ring装着がそれぞれ1例であった.手術死 亡2例( $40 \%)$ であった.非手術 4 例中2例死亡 $(50 \%)$ であっ た.また合併症を有さない12例中, 手術施行は1例で上行 置換を行い,生存している.非手術11例むすべて生存して いる.【考察、まとめ】 TEEを全例施行,合併症の有無を 考慮し,血流開存型全て,血流閉塞型は上行大動脈径が $50 \mathrm{~mm}$ 以上が適応，としている.全手術死亡率は $33.9 \%$ で あるが,合併症を有する症例では術前の状態も悪く,血流 開存,閉塞に関わらず手術死亡率はそれぞれ $52 \%, 40 \%$ と 高かった.1991年より GRFglueを導入し(11例),解離腔閉 鎖,冠状動脈固定, 弁輪吊り上げ固定など,手術操作が容 易になり,また超急性期の脆弱な動脈壁を強固にし止血 操作も容易となり,手術死亡は 3 例 $(27.2 \%)$ と改善し た.GRFglueは成績向上に有用である.

\section{S-2-2 超急性期 A 型大動脈解離治療方針の検討}

市立静岡病院心臟血管外科

島本光臣, 山崎文郎, 系井真一, 冲山光則, 上野孝史, 中井真尚、佐原寿史

[目的] 我々は過去 10 年間急性 $\mathrm{A}$ 型解離に対しnon extended手術の方針をとった。発症 5 日以内急性 A 型 大動脈解離症例の手術例を中心に検討を加え方針と術 式の妥当性を報告する。

[対象亡基本方針］以下の方針で 10 年間に手術施行 した発症 5 日以内の急性 A 型解離45例（男性32例, 女 性13例，平均年令58歳）と同時期収容した非手術早期 血栓閉鎖20例を対象とした。基本方針：1）血栓閉塞型 をのぞき80歳以下は全例緊急手術.2)大動脈造影20例 中破裂死 2 例のため、C T と超音波の診断のみにて手 術. 3)循環停止下に検索し(1)上行弓部に解離口が存在 しないときは上行置換、(2)上行弓部解離口はhemiarch 切除、(3)左鎖骨下動脈近傍解離口は上行弓部全置換. 4) 大動脈弁置換は可能な限り回避. 5)補助手段は初期 は循環停止之脳分離体外循環を用いたが、中期以降は 逆行性脳灌流（以後CRCP）を用い全例 open distal anas tomosis.

[手術症例の中枢解離[1の位置之術式]

解離口の位置は上行 23 例, 上行弓部5例, 弓部9例, 下行8例で、術式はentry閉鎖1例，上行置換 24 例, hem iarch 13例, 上行弓部全置換 1 例, composite graft 4 例。DeBakey II 型 7 例を除く中枢解離口切除例は28例、 非切除は10例となる。 composite症例を除きARに対し ては特別の吊り上げを行わず中枢側断端】惊補強のみ を行った。3 層フェ川補強11例, 他は 2 層フェ補強とし 解離胩に糊を注人。補助手段には体外循環のみ8例, 循環停止2例, 脳分離7例, CRCP 28例行った。

[結果] 非手術早期血栓閉鎖型：早期死亡 2 例 ( $10 \%)$, 再解離早期手術 2 例，慢性期手術 2 例。

手術症例；早期死亡：3 例、術後早期脑障害：一過性 2 例, 遠隔期死亡 5 例, 8 年生存率 : $65 \%$, 解離腔血栓 閉塞率: $30 \%$, 残存解離手術：3 例, 大動脈弁閉鎖不全 2 度以上: 0 例

[まとめ]循環停止下に解離口を検索し切除範囲を 決定する限り術前の大動脈造影は不必要である。近接 期成績より早期血栓閉鎖型はU L P を認めても手術適 応としない。CRCPは急性 A 型解離には非常に有用であ る。マルファン症例を除けば中枢解離口非切除と切除 例の生存率に差はなく、解離腔残存率は高いが、遠隔 期の瘤拡大率, 生存率, AR残存率よりhemiarchを多用 し、フェル補強のみにてAVRを回避するnon extended術 式は妥当性を持つ。 


\section{S-2-3 超急性期 A 型大動脈解離緊急手術症例の検討}

埼玉医科大学第一外科

上田恵介, 横手祐二, 許 俊鋭, 朝野晴彦, 田邊大明, 尾本良三

【目的】A型急性大動脈解離では早期診断に基ずい た緊急手術の成否が患者予後を左右すると考えられ， 当教室では I C Uでの経食道エコー診断のみで緊急手 術を施行してきた：本報告の目的はこの間施行した手 術症例のうち発症 5 日以内の超急性期 $\mathrm{A}$ 型大動脈解離 の緊急手術症例について手術成績を検討する事である

【対象】最近10年間の超急性期緊急手術症例は67例で， 発症から手術までの時間は $24 \pm 29$ 時間であった。手術 方法は原則として上行大動脈置換術とし,AR合併症例 及び近位弓部にIntimal Tear(IT)が認められた症例に は必要に応じて追加手術を施行した。手術成績は手術 死亡率（術後30日以内死亡率）を用いて検討した

【結果】1167例のうち30日以内死亡は17例で25.4\%で あった:これは急性期を経過し得た $\mathrm{A}$ 型症例の手術死 亡率9.5\%と比較して有意に高值であった。(2ITの存在 部位別の死亡率は，上行大動脈で $16 \%$ ，近位弓部大動 脈で36\%，下行大動脈（逆行解離）で30\%であった。

(3) 2 度以上のAR合作聇例は 33 例あり，死亡 9 例 (29\%) 之 高率であったため，さらに検討を加えた。(4)ITの大動 脈弁輪からの距離之手術手技により死亡摔を検討する 之, (i) ITが大動脈弁輪から20mm以内に浔められた症例 のうち，上行大動脈置換 +弁吊り上げ術を施行した7例 では4例 (57\%)が死亡し，さらに生存例3例共慢性期にバ ルサルバ洞動脈㾞を認めた 一方弁付きグラフトを用 いた5例の死亡例はなかった（i i ITが大動脈弁輪よ り $20 \mathrm{~mm}$ 以上離れていた症例では，上行大動脈置換＋弁 吊つり上げ術を施行した7例に死亡例はなかった。(5) ITが近位弓部に認められた22例のうち上行大動脈置換 手術のみ施行した10例之上行弓部置換手術を行った 12 例では死亡率に差はなかったが (40\%:33\%)，上行大動脈 置換のみを行った生存例中2例が慢性期に弓部置換手 術を必要とした: 【結論】(1)超急性期 $\mathrm{A}$ 型大動脈解離 の緊急手術成績は手術死亡率 $25 \%$ 之極めて不良であっ た：(2)AR合併症例に対する手術成績はIntimal Tearの 位置に関連し,大動脈近傍に位置した症例では弁付き グラフトを用いた手術が弁吊り上げ術に比較して良好 な成績であった。(3)近位弓部大動脈にIntimal Tearを 認めた症例では上行置換術之上行弓部置換術との間に 差は認められなかったが、手術死亡率は高率であり、 検討を要するところである
S-2-4 A型大動脈解離に対する超急性期手術施行例 の検討

秋田大学医学部心䁍血管外科

関根智之，阿部忠昭，栗林良正，関 啓二，

柴田芳樹，山岸逸郎，松川 誠，J.Chanda

（目的）急性A型大動脈解離例の救命には，発症直 後の致命的合併症防止の面より, 早期外科治療が必要 である。われわれは本疾患に対しては緊急手術を原則 とし，さらに現在では根治性の追及とともに上行弓部 大動脈置換を積極的に施行し，遠隔期大動脈病変の回 避，再手術の予防に努めている。今回，これらの症例 に対する手術成績を報告するとともに，拡大手術の遠 隔成績に及はす有用性を報告する。

（対象）1986年以降のA型大動脈解離手術例は36例, このうち発症 5 日以内の超急性期例は29例（男16, 女 13，平均年齢48.4歳）であった。26例における解離様 式はDeBakey I型21例，II型 2 例, IIIb逆行性解離6例で, Marfan 症候群合併例は 7 例であった。29例中26例 (92.3\%) は発症48時間以内の緊急手術例であった。 手術々式は1991年までの17例（前期）では超低体温循 環停止を併用，上行大動脈置換 8例，Collins手術 2 例， 上行弓部置換 1 例, Cabrol手術 2 例を行った。1992年 以降の12例（後期）では弓部への解離波及例には中等 度低体温下（25～28度）の脳分離体外循環を積極的に 併用しつつ, 上行大動脈 5 例, 上行弓部置換 5 例, Piehler手術 2 例を施行した。術前合併症は前期 2 例 (心タンボナーデ），後期 3 例（心タンボナーデ 3 ， 心筋梗塞 1) に認めた。

（結果）手術死亡は前期 3 例（LOS 1, 脳合併症 2), 後期 1 例 (遺残解離腔破裂) であり，後期では上行弓 部置換例の頻度が有意に増えたが，手術死亡率は減少 した。手術成績を術式とともに示す（手術死亡）。

\begin{tabular}{|c|c|c|c|c|}
\hline \multicolumn{4}{|c|}{ 上行 $/$ Collins 上行弓部 Cabrol型手術 } & 計 \\
\hline & $10(2)$ & $2(1)$ & $5(0)$ & $17(3,17.6 \%)$ \\
\hline 後期 & $5(0)$ & $5(1)$ & $2(0)$ & $12(1.9 .1 \%)$ \\
\hline
\end{tabular}

また，後期例での術中出血量は前期例に比較し，有 意に低値であった。前期の耐術14例中 3 例に遠隔期遺 残病変に対する再手術を必要としたが, 後期例では現 在まで再手術は認めていない。

（考察およびまとめ）急性A型大動脈解離症例の救 命には急性期の外科治療が必須であり，手術成績も向 上を認め, 良好となっている。術後解離腔の遗残およ びそれに起因する再手術の回避のためにも初回手術時 のEntry 部完全切除・人工血管置換が重要であり，急 性期例においても弓部解離波及例では，上行弓部置換 を積極的に採用することにより，さらに良好な遠隔成 績が期待できると考えられる。 


\section{S-2-5 超急性期A型大動脈解離の外科治療成䋶}

岸和田德洲会病院心䑏血管外科 ${ }^{1}$, 循環器内科 ${ }^{2}$, 和歌 山医大一外 ${ }^{3}$ 東上震一 ${ }^{1}$, 西岡武彦 ${ }^{1}$, 森俊文 ${ }^{1}$, 山本修司 ${ }^{1}$, 横井良明 ${ }^{2}$, 内藤泰影 ${ }^{3}$

【目的】A型大動脈解離に対する急性期手術におい て，（1）超低体温循環停止下に大動脈遮断は行なわ ない.（2）大動脈開放下にentry部の完全切除. を基 本方針に手術を行なってきた．我々の手術方針の妥当 性を手術成績から検討する.【対象】1991.1 1995.7までの期間に，A型大動脈解離30例に対して外 科治療を行なった. この内発症5日以内の超急性期手 術は22例で, 年齢44〜90歳 (平均67.1歳), 男性 10例, 女性12例であった．超急性期手術を選択した病態は， 心多ポナーテ 15例（この内3例右冠動脈，1例弓部分枝の 血流障害, 2例で高度ARを合併）, 弓部分枝血流障 害2例, 降圧不良 - 疼痛持続を含む大動脈径应大 3 例, 弓部紛槅内破裂2例であった. 22例中8例 (36\%) にショッ クを合併しており，2例が気管内挿管されていた。

【手術術式】中等度低体温下, 上行大動脈置換を行なっ た初期の 2 例を除く 20 例は $20^{\circ} \mathrm{C}$ 以下（平均最低膀胱温 $18.2^{\circ} \mathrm{C}$ ) で循環停止し, entry部の完全切除を目指して 切除籁囲を拡大した結果16例が弓部再建（hemiarch 10例, total arch 6例）となった. ARに対して, 弁吊 り上げ固定術2例，Cabrol手術1例を追加した．他の4 例では上行置换のみでentryの切除が可能であった. 弓部再建時の脑灌流は超低体温の補助的手段として右 腋窝動脈1本送血2例, SVC逆行性送血18例を行なった. 解離㓐閉鎖は内外2枚のfelt stripを用いる方法で行ない， 復温時に吻合部を大動脈壁を含めてテフロクエルト・人工 血管で完全に被覆補強した。【結果】22例に手術死亡 は認めず, 呼吸不全から多臟器障害に陥った1例を3力 月後失った．循環停止を行なった 20 例の体外循環時間 158 342分（平均249分），脳分離灌流時間30１10分

（平均72分）。我々の脳保護法に起因する新たな中枢 神経障害はなかった。逆行性脳灌流18例中3例で術後 遷延する見当識障害を認めた。痚喀出不良に伴う呼吸 不全の発生は8例 $(40 \%)$ と高率で, 内3例が左開胸を 追加したdoor open法の症例, 6例に左反回神経麻㾇, 2例に左横隔膜神経麻㾇を合併していた。【考察及び まとめ】22例の超急性期手術で病院死 1 例 $(4.5 \%)$ と 良好な成績が得られ, 我々の手術方針の妥当性が示さ れたものと考えられる. open anastomosisによる確実 な吻合操作と吻合線の完全被覆により, 出血で難渋す る症例はなかったが, 術後の呼吸不全に対する予防・ 対策が重要な課題と考えられた。
S-2-6 拡大再建術一生存率, 再手術, 残存解離腔に 及ほす効果

札幌医科大学医学部第二外科

森下清文 数井暉久 高木伸之 田宮幸彦 小松作蔵

【目的】超急性期のA 型大動脈解離に対し，弓部再 建を含む拡大再建術を積極的に施行してきたので，そ の妥当性を検討した。

【対象・方法】1995年8月末までに発症5日以内に 外科治療を施行したA 型大動脈解離70例を対象とし た。術式は上行大動脈置換術 11 例, 上行+弓部大動脈 部分置換術9例, 上行+弓部大動脈全置換術37例, 上 行+弓部+下行大動脈置換術 9 例, その他 4 例であっ た。合併手術は弁挙上術 18 例，大動脈基部置換術 11 例, 冠状動脈再建術4例, 大動脈弁置換術 1 例であっ た。弓部大動脈再建は, 腕頭動脈, 左総碩動脈の選択 的脳灌流下に，分枝付き人工血管で行った。最近，以 下の改良を加えた。(1)人工血管末梢側吻合終了後，四 本目の側枝より順行性灌流を開始し，加温開始前に左 鎖骨下動脈再建を行い, 左椎骨動脈領域の虚血を予防 する，(2)解離断端の閉鎖・補強にGRF glueを使用す る, (3) Il b 型逆行解離の場合, entry を含め近位側下 行大動脈を可及的に置換することである。以上の症例 に対し上行+弓部大動脈全置換術, 上行+弓部 + 下行大 動脈置換術を拡大再建群（46例），残りの症例を対 照群 (24例) と定義し, 治療成績 ·再手術 - 残存解 離腔の血栓化を比較した。

【結果】(1)拡大再建群の早期死亡率は $16 \%$ で, 対照 群と有意差はなかった。死亡例の大半は, 冠状動脈解 離を伴ったショック例もしくは複数臓器の虚血例で, これら high risk 症例を除いた39例の死亡率は5\%であ った。(2)早期死を含む拡大再建群の5年生存率は73土 $7 \%$ で, 対照群と有意差はなかった。(3)術後 5 年の非 再手術率は拡大再建群 $74 \pm 12 \%$, 対照群 $63 \pm 21 \%$ と 有意差はなかったが, 再手術の内容は対照群が弓部置 換であるのに対し，拡大再建群は残存解離腔の瘤化に 伴う手術であった。拡大再建群の再手術3例は全例, 胸腹部全置換を行い, その内, マルファン症候群の2 例は大動脈全置換となった。これら3例の広範囲型動 脈解離は根治され，全例生存している。(4)遠隔期の残 存解離腔血栓化は I 型解離では術式間に差はなかった が, II b 型逆行解離で上行+弓部+下行大動脈置換が 83 \%の血栓化率を示した。

【考察および結語】拡大再建術は，治療成績が良好な こと, 二期手術により根治の可能性を持つこと，高い 血栓化率を示すことから，超急性期に本術式を第一選 択とすることは, 冠状動脈解離を伴ったショック例も しくは複数臟器虚血例を除き妥当であった。 
S-3-1 閉塞性動脈硬化症の高齢者重症阻血肢の治療 成績と問題点

川崎医科大学胸部心臓血管外科

正木久男、稲田 洋、村上泰治、森田一郎、藤原

〔目的〕高齢者重症阻血肢に対する治療は、救肢と ともに生命予後などを考えあわせた選択をしなければ ならない多くの問題点を有している。今回その問題点 を解明することを目的とした。

〔対象および方法〕1976年 1 月〜1995年 7月まで当 科で入院加療した閉塞性動脈硬化症は852例で、その うちFontaine III、IV度251例、263肢を対象とし、その 中で75歳以上を高齢者群として治療成績を全症例と比 較検討した。

〔結果〕高齢者群は77例78肢で男性62例、女性15例、 Fontaine III度24肢、IV度54肢であり、女性とIV度の症 例の占める割合が多かった。主な術前合併症は、高柃 者群では高血圧 $58 \%$ 、糖尿病 $21 \%$ 、脳血管障害 $18 \%$ 、 虚血性心疾患16\%で、全症例群とは差を認めなかった。 病変部位には差はなく複合病変を伴っている例が大多 数であった。初回治療は、全症例群でバイパス154、 TEA28、腰交切49、切断37（大切断24）、保存的療法 26、高粉者群はそれぞれ、42、8、6、16(14)、14で あり、高齢者群に大切断例の占める割合が多かった。 バイパスは高齢者群で非解剖学的バイパスが $46 \%$ 占め ていた。初回切断例は脳血管障害を伴っている症例に 多かった。早期救肢率は、全症例で $92 \%$ 、高齢者群で 91\%と有意差はなかった。血行再建例における累積開 存率は、全症例群で 1 年 $80 \% 、 3$ 年 $69 \%$ 、5 年 $57 \%$ 、 高歯者群では、それぞれ67\%、53\%、53\%であり、高 齢者群は 1 年以内の閉塞が高い傾向であったが、その 後は有意差は認めなかった。早期死亡は全症例で11例、 高齢者群 4 例で、死因は心疾患が約半数占めていた。 術後大切断例は、全症例で21肢、高齢者群で 7 肢に認 め全て術後 2 年以内であった。晚期死亡の死因は、高 歯者群で、虚血性心疾患13例、癌12例、脳血管障害 4 例、腎不全 2 例、その他 4 例であった。

〔まとめ〕 (1)高齢者重症阻血肢は、女性とFontaine IV 度の占める割合が多く、来院時大切断せざるおえな い症例も多く、特に脳血管障害合併例に多数認められ、 早期の診断の必要性があげられる。(2)高路者であって も救肢率に差はないが、血行再建例では 1 年以内のグ ラフト閉塞が多く、薬物療法を含めた十分な管理が必 要である。(3)生命予後に関しては、術前、術中、術後 を含め、長期にわたり、虚血性心疾患の存在を常に念 頭に入れた十分な治療か㴗求される。
S-3-2 Activities of daily living と冠動脈疾患 からみた救肢、救命へのstrategy

川崎市立川崎病院外科、浦和市立病院外科*

松本賢治、白杉 望、納賀克彦、朝見淳規*戸戸倉康之*

【目的】高龄者重症阻血肢の QOLと生命予後を踏ま え、特にactivities of daily living(ADL) と冠動脈 疾患(CAD) に着目し、救肢、救命への治㞠方針を検討 した結果、若干の知見を得たので報告する。

【対象と方法】最近 9 年間に経験された 70 歳以上の 62 例を対象とした。年秢首より79歳までの37例を $\mathrm{A}$ 群 （平均73.8歳、男女比 $24: 13$ ）、80歳以上の 25 例を B 群（97歳まで、平均85.2歳、男女比13:12）と分類し、 それぞれADLとCADの評価および治療法、成績等を比較 分析した。なお、ADL はperformans status の判定基 準（O度:正常〜IV度:寝たきり）や簡易知能テス卜、 脳血流シンチ、精神的支え（キーパーソン）の有無等 で評価し、またCAD は主にdipyridamole負荷心筋タリ ウムシンチ（心筋SPECT）にて評価した。

【治療法】原則として、(1)ADL がO、I 度例は血行再 建術の、III、IV度例は一次的肢切断術の適応とし、II 度例は症例毎に検討した。(2)心箭SPECT 陽性例は冠動 脈造影を施行し、冠動脈バイパス術(CABG) は救肢に先 行させた。CADでCABG困難例は一次的肢切断術とした。

CABGは両群とも 2 例で、血行再建術はA 群が24例 (64.9\%)、B群が 8 例（32.0\%）で施行された。な お、血行再建術はできる限り解剖学的バイパス術を第 一選択とし、腹部は腹膜外到達法を採用した。

【結果】(1)ADL:簡易知能テストや脳血流シンチは必ず しも良く相関せず、A 群はO度 $62.2 \% 、 B$ 群はIV度 $44.0 \%$ と暦年路とほぼ一致しており、キーパーソンの 存在が大きかった。(2CAD:心筋SPECTで良く反映され、 A 群が37.8\%、B群が32.0\%と有意差を認めなかった。 (3)生命予後： 血行再建、救肢群 肢切断群

\begin{tabular}{|l|ll|ll|}
\hline 手術死亡 & $(\mathbb{A} 4 / 24$ & $\mathbb{B} 1 / 8$ & $(\mathrm{~A} 1 / 8$ & $\mathbb{B} 2 / 14$ \\
& $(16.7 \%)$ & $(12.5 \%)$ & $(12.5 \%)$ & $(14.3 \%)$ \\
\hline \multirow{2}{*}{ 遠隔死亡 } & $(\mathrm{A} 7 / 24$ & $\mathbb{B} 2 / 8$ & $(\mathrm{~A} 3 / 8$ & $\mathbb{B} 5 / 14$ \\
& $(29.2 \%)$ & $(25.0 \%)$ & $(37.5 \%)$ & $(37.5 \%)$ \\
\hline
\end{tabular}

治療法と年秢層の間に有意差を認めなかった。手術死 亡例は主に心筋SPECT、CABG創始前で心筋便塞に起因し た。後期はMRSA肺炎が多く、CABGに死亡例はなかった。

【考案と結語】 1 1ADLの評価は暦年齢と相応していた が、治療方針の决定に有用で、キーパーソンの有無も 重視される。(2心筋SPECTでのCAD評価は簡便、非侵襲 的で優れており、生命予後向上への寄与が期待され る。(3)CAD 陽性例では、暦年踰によらず積極的CABGを 考虑し、CABG先行の二期的手術が推奖される。CABG困 難例では救肢に固執しない方が安全であろう。 
S-3-3 高齢者の重症阻血肢に対する治療方針と予 後に関する検討

東京大学医学部第一外科

安原洋, 重松宏, 北川剛, 細井温, 重松邦広, 小見山 高士, 新本春夫, 大城秀巳, 布川雅雄, 武藤徽一郎

〔目的〕高齢者の重症阻血肢に対する治療方針は, 救肢のみでなく患者の全身状態, 術後ADLなども考虑 し, 多角的に決定する必要がある. 高龄者の重症阻血 肢で患者年龄が治療方針，患肢の予後，術後ADLにど のように影響したかを retrospectiveに検討した。

〔方法〕1980-1994年に当科外来を受診した下肢閒 塞性動脈硬化症809例のうち来院時の症状がFontaineIII 度(F-III), FontaineIV度(F-IV)の260例(32\%)を対象とした。 年齢の影響を検討するため対象患者を75歳以上92例 (高齢群)と75歳未満168例(対照群)の2群に分け, 保存 的治療法, 外科的治療法(PTAを含む)の別で成績を検 討した。また，"肢切断"は足関節より近位の切断とし， 患者の術後ADLは患肢のFontaine分類改嗞度から推测 した. 治療方針は閉塞病変の広がりや患者りスク，併 存疾患の有無と関連するため, 病变の占拠部位, 併存 疾患と治療方針の関連についても年耣別に㭘討した。

〔結果]75歳以上の高龄者が占める割合はF-III35例 (35\%)，F- IV 55例(35\%) と両群ほほ同様で，F-III, F-IV ともに単分節病変の症例で保存的療法が選択される傾 向がみられた，手術術式をみると，F-IIIでは年龄に関 係なく大腿動脈より近位の血行再建術が多く(高龄群 $23 \%$, 対照群 $26 \%$ ), F-IVでは大腿部以遠の末梢侧血行 再建術が多くみられた(高龄群 $40 \%$, 対照样 $30 \%$ )。また， F-IVの高齢群には動脈硬化に起因する心血管系の合併 症が明らかに多かった. 来院時直ちに"肢切断"が必要 であった症例は全例F-IVに含まれ，高此群25例中9例 (36\%), 対照群12例中7例(58\%)であった。また，血行 再建術後に"肢切断"を要した例はF-IVの対照磁に多か った（48例中11例(23\%)）。ただし，F-IVで来院直後 と術後の"肢切断"例をあわせると, 対照群では105例 中21例 (20\%), 高秢群では57例中9例(16\%) と"技切断" の割合は年龄に関係なくほほ同様であった。"肢切断" 以外の症例で治療後の症状をみると，保存的治療後に F-IIIでは高歯群 $64 \%$, 対照群 $75 \%$, F-IVでは高踰群 $83 \%$, 対照群80\%でFontaineII度まで症状改善が得られたが, 外科的治療を行えば，F-III，F-IVいずれも作齿に関係 なく90\%以上の例で同様な症状改善が得られた。

〔考察とまとめ]F-IVの䦥塞性動脈硬化症では高齢 群で来院時に血行再建術の適応とならない重症例が多 いが，血行再建術を行った例では患肢の機能はより良 好に保たれていた，高龄者の重症阻血肢ではF-IVの症 例で"肢切断"の時期を逸することなく皘極的な血行再 建術を行うことが肝要であると考えられた。
S-3-4 高龄者重症阻血肢の遠隔期 Qual ity of Life 一血行再建術莯物療法か-

1.4口第一外科

藤威影太郎, 斎藤 聰. 山下晃正, 土生川光成, 占村耕一，久我貴之，善甫宣哉，江里健輔

【目的】下肢閉塞性動脈硬化症（以下ASO)における Fontaine III，N度の重症阻血肢は手術㞠法の絶対的 適応であるためたとえ高龄者であろうとも全身状態か 許されれば、教室でも積栖的に血行再建術を行ってき た。しかし、種々の理由で血行画建術を施行せず、楽 物療法を行った症例もある。今回我々は70藏以上の高 齢者重症阻血肢を血行再建群と薬物療法群の 2 群に分 けて比較し、それぞれの治療の意義について知ること を目的として検討した。

【对象と方法】1995年6月までに当科で経験したASO のうち70歳以上のFontaine III, IV 度症例は67例73肢 であった。そのうち血行再建術が行われたのは58例64 肢（血行再建群）血行再建が湤行されす薬物療法を 施行したもの9例9肢（薬物療法群）であった。いずれ も治療に関与して下肢切断された症例はなかった。入 院時症状は血行再建群Fontaine III度41肢、IV度23肢。 楽物癔法群 III度3肢、 V 度6肢で画群間に有意差はな かった。平均年龄は血行再建群76嵅、薬物旗法群79歳 で2群間に有意差はなかった。血行再建群のうち25肢 は多発性病变を有し21肢に対して完全血行再建術を施 行した。薬物療法群で血行再建術を施行しなかった理 由とその例数は全身状態不良6例 (心不全 4例, 䋊梗 塞,肺窝各 1 例）、末梢run off不良 2 例、乎術拒否 1 例 であった。

【結果】楽物撩沠群にやける遠隔期怔状（平均観察 期間：1年10力月）はFontaine II度3肢、III度2肢、V 度4肢でこれらうのうち遠隔期に症状が悪化し肢切断に 至った症例はなかった。血行再建群のうち死亡症例を 除いた遠隔期症状（平均観察期間：4年9力月）は

Fontaine I 度23肢、II度12肢、III度2肢、IV度2肢て 症状の改善された症例が有意に多かった。初回血行再 建術後遠隔期に肢切䉼に至ったのは3肢で肢救済率は 95\%であった。手術死亡は2例（3\%）で死因は心筋梗 塞、心肺不全それぞれ1例であった。

【結語】(1重症阻血肢に対してはたとえ高㱓者であ ろうとも全身状態が許される限りQuality of Life 向 上のために皘的に血行再建術を行い、さらに多発性 病変に対しても完全再建術を試みるぐきである。 (2)高龄者重症阻血肢に刘する薬物療法は血行再建群ほ ど劇的な刘果は期待できないが、症状悪化の防止は十 分期待できる。 
S-3-5 高龄者重症下肢虚血病変に対するバイパ ス術一BKPA以下へのバイパスの意義一

姫路循環器病センタ一心腀血管外科

向原伸彦、小澤修、麻田達郎、桶上哲哉、大保 英文、顔邦男、岩橋和彦、

目的：われわれは、重症下肢虚血に対してはた とえ高龄者であろうとも積極的に下肢バイパス術 を施行してきた。今回とくにbelow knee popliteal artery(以下BKPA) 以下へのバイパスに注目し、 その成績を検討したので報告する。対象および方 法 : 高龄者を70歳以上、重症下肢虚血をFonta ine III 度以上の症状と定義し、1987年1 月から1995 年8 月までの症例を対象とし、以下の 4 群に分け 検討した。I 群: 高龄者重症下肢虚血例でBKPA以 下へのバイパスを施行した群で30例30肢、平均年 龄75歳(70-92)、男女比26:4、BKPAへのバイパス 22、infra PAへのバイパス8 肢であり、1 例6mm EXS グラフトを使用したが他はすべて大伏在静脈 （SV）を使用した。II群：高龄者重症下肢虚血例の うち、その他の手術が行われた群24例26肢、平均 年龄81歳(70-84）、男女比20:4、施行された手術 は腑窝大腿動脈バイパス $(\mathrm{Ax}-\mathrm{F})$ が 12 、大腿膝上滕 窝動脈バイパス(F-P) が4、Ax-F+F-Pが7、その 他が3 であった。III 群:70 葴未満の重症下肢虚 血例でBKPA以下へバイパスした群で18例21肢、平 均年龄57歳(26-68) 、男女比16:2、BKPAへのバイ パス12、infra PAへのバイパス9 肢であり1例を のぞきSVを使用した。IV群:70 歳未満、間歇性跛 行にてBKPAよ下へバイパスを行った群で22例26肢、 平均年龄59歳(40-69) 、男女比21:1、BKPAへのバ イパス12、infra PAへのバイパス14肢で全例にSV を用いた。結果) 各群のprimary patency (pp)は 5 年でI 群61\%, II群55\%, III 群71\%, IV群74\% で、 Secondary patency（sp)はそれぞれ63\%,59\%,79\%, 93\%、1 imb salvageは5 年で $91 \%, 100 \%, 95 \%, 100 \%$ であった。5 年生存率は $28 \%, 19 \%, 76 \%, 93 \%$ となっ た。各群間の比較では、ppおよびlimb salvageに おいては各群間に有意差なく、SpにおいてI 群と IV群間、II群とIV群間にP $<0.1$ の傾向差を認めた。 5 年生存率ではI 群とIV群間にp<0.01の、II群と IV群間にP $<0.001$. の有意差を認めた。考案および 結語：高龄者におけるグラフト閉塞の原因は動脈 硬化性病変の進展が最も多く、また、生活レベル の低下からグラフトが閉塞しても症状として気付 かれることが少なく、graft salvage できずに secondary patency の低下につながった。高齡者 の5 年生存率は低いもののBKPAバイパスのprimary patencyおよびlimb salvageは良好であり、積 極的に施行すべき術式と思われた。
S-3-6 Complete revascularizationの意義

旭川医科大学第一外科

東 信良, 笹嶋唯博, 郷一知, 稻葉雅史, 山本浩史，羽賀將衛，久保良彦

【目的】高齢者における肢の温存は生命予後に重要 な意義を持つと考えられ、そのためには積極的な血行 再建が不可欠である。今回は、教室の成績から高齢者 に対する血行再建術の適応、方法、治療成績について 検討した。

【対象と方法】1980年以降に教室で血行再建を行っ た重症阻血肢（FontaineIIIまたはIV度）は 196例 211 肢であり、このうち75歳以上の重症阻血肢71例77肢 （36.5\%）を対象として、75歳以下の若年者群と比較 した。術式は骨盤型閉塞に対しては、大動脈大腿動脈 バイパスを22肢、腸骨動脈大腿動脈バイパスを 6 肢、 腋窝大腿または大腿大腿動脈バイパス (EXB) を23肢に 行い、大腿下腿型閉塞に対しては、肢および肢長の可 及的温存を重視し complete revascularizationを目的 に、これらのバイパスと同時あるいは単独に膝窝以下 へのバイパス 57 肢 (膝窝 33 肢、下腿22肢、足関節以下 2 肢）に行った。

【結果】高齢者群では若年者に比べ、FontaineIV度 の占める割合が高く $(68.8 \%$ vs $59.7 \%)$ 、多発閉塞の 傾向にあるが、複数 Risk factor保有率には差を認め なかった (44.2\% vs $50.7 \%)$ 。手術死亡は、高龄者 群で 2 例 2.6\% (内訳は心筋梗塞と急性堅不全) で、 若年者群の 3 例 $2.2 \%$ と差を認めなかった。術式は高 齢者群で EXBの割合が有意に多かった (45.1\% vs $15.3 \%)$ 。高齢者群のグラフトの 5 年累積開存率は、 assisted primary patency rate で72.5\%であり、 EXB 群に閉塞率が高かったものの、若年者群 $(81.1 \%$ ）と有意差を認めなかった。術後早期の肢切断は、小 切断6 肢、大切断 2 肢の計8 肢 (10.4\%) であり、 $86.0 \%$ の患者が歩行退院した。遠隔期の肢切断は 3 例 で、 5 年累積救肢率は $91.3 \% 、 5$ 年累積生存率は 49.5 \%であった。

【結語】高齢者重症阻血肢に対する complete revascularization は、術式の工夫により低い手術死 亡率で救肢と歩行機能の回復を可能にし、quality of lifeの向上と良好な生命予後を得た。しかし、下肢阻 血発症前から歩行不能であった例や慢性透析例の生命 予後は不良であり血行再建の適応は極めて限定される べきであると考えられた。 